\title{
PERMASALAHAN DAN KENDALA PENYELESAIAN SENGKETA KONSUMEN MELALUI BADAN PENYELESAIAN SENGKETA KONSUMEN (BPSK)
}

\author{
Kurniawan \\ Fakultas Hukum Universitas Mataram \\ E-mail: kurniawan3377@yahoo.co.id.
}

\begin{abstract}
Consumer dispute can be resolved through on courts or outside the court based on voluntary choice of the parties. Settlement of dispute through the court provisions on the article 45. Dispute of the settlement can be solved out the court by using Consumer Dispute Settlement Body (BPSK).The purpose of establshing BPSK is to protec consumer and producer by designing consumer protection system that contain legal certainty and transparency the information. The existence of BPSK expected equality of justice especially to consumer that aggrieved by consumer. It because the dispute between consumer and producer generally involved in small value so that the consumer hesitate to registered his case to judicial process. There is no adequate between the court fee and indemnification perceived. The problems that the decision of BPSK has characteristic final and binding however it can be carried out to the district court and the decision cannot be executed directly or realized.
\end{abstract}

Keywords: consumers right, consumer's protection, dispute resolution.

\begin{abstract}
Abstrak
Sengketa konsumen dapat diselesaikan melalui Pengadilan ataupun luar Pengadilan berdasarkan pilihan sukarela dari para pihak. Penyelesaian sengketa melalui jalur pengadilan mengacu kepada ketentuan yang berlaku dalam peradilan umum dengan memperhatikan ketentuan Pasal 45 UUPK. Penyelesaian di luar pengadilan dapat dilakukan dengan memanfaatkan Badan Penyelesaian Sengketa Konsumen (BPSK). Tujuan pembentukan BPSK adalah untuk melindungi konsumen maupun pelaku usaha dengan menciptakan sistem perlindungan konsumen yang mengandung unsur kepastian hukum dan keterbukaan informasi. Keberadaan BPSK diharapkan akan menjadi bagian dari pemerataan keadilan, karena sengketa di antara konsumen dan pelaku usaha biasanya nominalnya kecil sehingga konsumen enggan untuk mengaj ukan sengketanya di Pengadilan. Hal yang menjadi persoalan adalah putusan BPSK yang bersifat final dan mengikat, hanya saja putusan tersebut dapat dilakukan upaya keberatan ke pengadilan negeri dan putusan tersebut tidak dapat langsung eksekusi atau dilaksanakan.
\end{abstract}

Kata kunci : hak konsumen, perlindungan konsumen, penyelesaian sengketa

\section{Pendahuluan}

Pesatnya perkembangan ekonomi nasional telah menghasilkan diversifikasi produk barang dan/atau jasa yang dapat dikonsumsi oleh masyarakat. Kemajuan ilmu pengetahuan, teknologi komunikasi dan informatika juga turut mendukung perluasan ruang gerak transaksi barang dan/jasa hingga melintasi batas-batas wilayah suatu negara. Kondisi yang demikian pada satu pihak sangat bermanfaat bagi kepentingan konsumen karena kebutuhan akan barang dan/ atau jasa yang diinginkan dapat terpenuhi serta semakin terbuka lebar kebebasan untuk memilih aneka jenis kualitas barang dan/atau jasa sesuai dengan kemampuannya. Di sisi lain, kondisi dan fenomena tersebut dapat mengakibatkan kedudukan pelaku usaha dan konsumen menjadi tidak seimbang, dimana konsumen cende-rung dijadikan obyek aktivitas bisnis dari pelaku usaha untuk meraup keuntungan sebesar-besarnya melalui kiat iklan, promosi, cara penjualan, serta penerapan perjanjian standar 
yang merugikan konsumen. ${ }^{1}$ Kerugian konsumen secara garis besar dapat dibagi menjadi 2 (dua) yaitu: pertama, kerugian yang diakibatkan oleh perilaku penjual yang memang secara tidak bertanggung jawab merugikan konsumen; kedua, kerugian konsumen yang terjadi karena tindakan melawan hukum yang dilakukan pihak ketiga sehingga konsumen disesatkan yang pada akhirnya dirugikan. ${ }^{2}$

Faktor utama yang menjadi kelemahan konsumen adalah tingkat kesadaran konsumen akan hak-haknya yang masih rendah. Hal ini disebabkan oleh rendahnya pendidikan konsumen. Oleh karena itu kehadiran Undang-Undang Perlindungan Konsumen dimaksudkan menjadi landasan hukum kuat bagi pemerintahan dan lembaga perlindungan konsumen swadaya masyarakat untuk melakukan upaya pemberdayaan konsumen melalui pembinaan dan pendidikan konsumen.

Perhatian dunia internasional terhadap perlindungan konsumen sebagai korban mulai muncul dengan ditetapkannya Resolusi PBB No. 39/ 248 tanggal 16 April 1985 yang isinya menentukan bahwa perlindungan konsumen dari bahaya-bahaya terhadap kesehatan dan keamanannya, promosi dan perlindungan kepentingan sosial ekonomi konsumen, tersediannya informasi yang memadai bagi konsumen untuk memberikan kemampuan mereka melakukan pilihan yang tepat sesuai kehendak dan kebutuhan pribadi, pendidikan konsumen, tersedianya ganti rugi yang efektif dan kebebasan untuk membentuk organisasi konsumen atau yang relevan melindungi konsumen. ${ }^{3}$

Didukung oleh perkembangan politik dan ekonomi di Indonesia, maka lahirlah UU No. 8 Tahun 1999 tentang Perlindungan Konsumen (untuk selanjutnya disebut UUPK) yang disahkan oleh Presiden RI pada tanggal 20 April 1999

\footnotetext{
1 Penjelasan umum atas Undang-Undang Republik Indonesia No. 8 Tahun 1999 tentang Perlindungan Konsumen (Lembagan Negara RI Tahun 1999 Nomor 42).

2 Ahmad Ramli, "Perlindungan Hukum Terhadap Konsumen Dalam Transaksi E-Commerce", Jurnal Hukum Bisnis, Volume 18 Nomor 3 Tahun 2002, hlm. 14.

3 L. Parman, "Perlindungan Konsumen Dengan Sarana Hukum Pidana", Majalah IImiah IImu Hukum Jatiswara Terakreditasi DirjenDikti No. 34/ Dikti/Kep/2003, Fakultas Hukum Universitas Mataram, Vol. 20 No. 2 April 2005, hlm. 168-169.
}

dan berlaku efektif tanggal 20 April 2000. UUPK diharapkan melindungi kepentingan konsumen secara integratif dan komprehensif serta dapat diterapkan secara efektif di masyarakat. UUPK pada dasarnya melakukan pengaturan pada 2 (dua) subyek, yaitu pelaku usaha dan konsumen. Dalam perlindungan konsumen, sendi utama pengaturannya adalah pada kesederajatan antara konsumen dan pelaku usaha. Keberadaan pelaku usaha baru memiliki arti apabila juga terdapat keberadaan konsumen. Hal ini merupakan konsekuensi logis dari sendi-sendi pengaturan di bidang usaha, yaitu hak berusaha yang sama bagi setiap orang dan kepentingan konsumen merupakan tujuan akhir. Namun, fenomena yang nampak adalah kedudukan antara pelaku usaha dengan konsumen tidak seimbang dimana konsumen berada pada posisi yang lemah. Faktor Inilah yang kemudian menyebabkan terjadi perselisihan atau sengketa antara pelaku usaha dengan konsumen. ${ }^{4}$

Penyelesaian sengketa dalam mempertahankan hak-hak konsumen diatur pada Pasal 45 UUPK, yang menyebutkan bahwa penyelesaian sengketa dapat ditempuh melalui pengadilan atau luar pengadilan berdasarkan pilihan sukarela para pihak yang bersengketa. Penyelesaian sengketa di luar pengadilan dapat ditempuh melalui BPKS yang tugas dan wewenangnya antara lain meliputi pelaksanaan penanganan dan penyelesaian sengketa konsumen dengan cara melalui mediasi, arbitrase atau konsiliasi, yang selain sebagai media penyelesaian sengketa juga dapat menjatuhkan sanksi administratif bagi pelaku usaha yang melanggar larangan-larangan ter-tentu yang dikenakan bagi pelaku usaha. ${ }^{5}$ Permasalahannya adalah putusan BPSK yang bersifat final dan mengikat masih dapat dilakukan upaya keberatan ke Pengadilan Negeri dan putusan tersebut tidak dapat langsung dieksekusi. Di samping itu masih terdapat beberapa kendala lain dalam BPSK.

\footnotetext{
4 Ari Purwadi, "Telaah Singkat tentang Undang Undang Perlindungan Konsumen", Jurnal Hukum \& Keadilan, Fakultas Hukum Universitas Islam Indonesia, Vol. 3. No. 3. $2000, \mathrm{hlm} .117$

5 Abdul Halim Barkatullah, "Urgensi Perlindungan Konsumen Dalam Transaksi di E-Commerce", Jurnal Hukum, Fakultas Hukum Universitas Islam Indonesia No. 2 Vol. 14 April 2007, hlm. 260.
} 


\section{Pembahasan}

Secara harafiah arti consumer itu adalah (lawan dari produsen) setiap orang yang menggunakan barang. Tujuan penggunaan barang atau jasa itu nanti menentukan termasuk konsumen kelompok mana pengguna tersebut. Begitu pula Kamus Bahasa Inggris-Indonesia memberi arti kata consumer sebagai "pemakai atau konsumen". ${ }^{6}$ Dalam peraturan perundangan di Indonesia, istilah "konsumen" sebagai definisi yuridis formal ditemukan pada UUPK. Konsumen adalah setiap orang pemakai barang dan atau jasa yang tersedia dalam masyarakat, baik bagi kepentingan sendiri, keluarga, orang lain maupun makhluk hidup lain dan tidak untuk diperdagangkan (Pasal 1 angka 2 UUPK).

Pelaku usaha, masyarakat umum biasanya menyebutnya dengan sebutan produsen. Terkadang masyarakat mengartikan produsen sebagai pengusaha, namun ada pula pendapat yang mengatakan bahwa produsen hanya penghasil barang saja dan merupakan salah satu unsur dari pengusaha. UUPK menggunakan istilah Pelaku Usaha. Menurut Pasal 1 Angka 3, pengertian Pelaku Usaha adalah Setiap orang perorangan atau badan usaha, baik yang berbentuk badan hukum maupun bukan badan hukum yang didirikan dan berkedudukan di wilayah hukum negara Repu-blik Indonesia, baik sendiri mapun bersama-sama melalui perjanjian penyelenggaraan kegiatan usaha dalam berbagai bidang ekonomi.

Setiap orang pada suatu waktu tertentu dalam posisi tunggal/ sendiri maupun berkelompok bersama orang lain, dalam keadaan apa pun, pasti menjadi konsumen untuk suatu produk atau jasa tertentu. Keadaan yang universal ini pada beberapa sisi menunjukkan adanya berbagai kelemahan pada konsumen sehingga konsumen tidak memiliki kedudukan yang "aman". Oleh karena itu secara men-dasar konsumen juga membutuhkan perlindungan hukum yang sifatnya universal juga. ${ }^{7}$

\footnotetext{
6 Ibid

Sri Redjeki Hartono, "Perlindungan Konsumen di Indonesia (Tinj auan Makro)", J urnal Mimbar Hukum, Fakultas Hukum Universitas Gadjah Mada, Edisi Khusus No. 39/ X/ 2001, hlm. 147.
}

Perlindungan konsumen menurut Pasal 1 angka 1 UUPK adalah segala upaya yang memberikan kepastian untuk memberikan perlindungan kepada konsumen. Kepastian hukum yang dimaksud dalam pengertian ini meliputi segala upaya untuk memberdayakan konsumen memperoleh atau menentukan pilihannya atas barang/atau jasa kebutuhannya serta mempertahankan atau membela hak-haknya apabila di rugikan oleh prilaku pelaku usaha penyedia kebutuhan konsumen tersebut. ${ }^{8}$

Perlindungan hukum terhadap konsumen dapat dibagi dalam dua bagian. Pertama, No Conflict (pre-purchase), yaitu apabila tidak terdapat konflik atau tidak ada pertentangan, maka dapat dilakukan dengan dua cara yaitu legislation, dimana perlindungan hukum dilakukan dengan cara merancang dan menetapkan pelbagai peraturan perundang-undangan. Voluntary self-regulation, dimana perlindungan konsumen dilakukan melalui cara perancangan dan penetapan peraturan oleh pelaku usaha sendiri secara sukarela (voluntary) di dalam perusahaannya (baik barang maupun jasa). Kedua, apabila terjadi Conflict (post-purchase). Apabila terjadi konflik atau pertentangan antara konsumen dengan pelaku usaha, maka dapat diselesaikan melalui litigation, yaitu perlindungan hukum kepada konsumen yang terakhir adalah mengajukan perkara yang terjadi antara konsumen dengan pelaku usaha ke pengadilan atau ke BPSK. ${ }^{9}$

BPSK diadopsi dari model Small Claim Tribunal (SCT) yang telah berjalan efektif di negara-negara maju, namun BPSK ternyata tidak serupa dengan SCT. Sebagaimana diketahui SCT berasal dari negara-negara yang bertradisi atau menganut sistem hukum Com-mon Law atau Anglo Saxon memiliki cara berhukum yang sangat dinamis dimana yurisprudensi menjadi hal utama dalam penegakan hukum. Sedangkan Indonesia sistem hukumnya adalah

\footnotetext{
8 Az. Nasution, "Aspek Hukum Perlindungan Konsumen", J urnal Teropong, Edisi Mei 2003, Masyarakat Pemantau Peradilan Indonesia, hlm. 6-7.

9 J ohannes Gunawan, "Pemberlakuan Undang-undang Perlindungan Konsumen Terhadap PT. PLN Sebagai Lembaga Pelayanan Umum", Pro J ustitia, J urnal Hukum Triwulan Universitas Katolik Parahyangan, Tahun 19, Nomor 4, Oktober 2001.
} 
Civil Law atau Eropa Kontinental yang cara berhukumnya bersumber dari hukum tertulis (peraturan perundang-undangan). ${ }^{10}$ BPSK nampaknya didesain dengan memadukan kedua sistem hukum tersebut, dimana model SCT diadaptasikan dengan model pengadilan dan model ADR (Alternative Dispute Reso-lution) khas Indonesia.

BPSK adalah badan yang bertugas menangani dan menyelesaikan sengketa antara pelaku usaha dan konsumen. BPSK sebenarnya dibentuk untuk menyelesaikan kasus-kasus sengketa konsumen yang berskala kecil dan bersifat sederhana (Pasal 1 butir 11 UUPK). Dasar hukum pembentukan BPSK adalah Pasal 49 Ayat 1 UUPK dan Kepmenperindag Nomor 350/MPP/ Kep/12/2001 yang mengatur bahwa di setiap kota atau kabupaten harus dibentuk BPSK. BPSK pertama kali diresmikan pada tahun 2001, yaitu dengan Keputusan Presiden Nomor 90 Tahun 2001 tentang Pembentukan Badan Penyelesaian Sengketa Konsumen pada Pemerintah Kota Medan, Kota Palembang, Kota J akarta Pusat, Kota Jakarta Barat, Kota Bandung, Kota Semarang, Kota Yogyakarta, Kota Surabaya, Kota Malang dan Kota Makasar. Selanjutnya, dalam Keputusan Presiden No. 108 Tahun 2004 dibentuk lagi BPSK di tujuh kota dan tujuh kabupaten berikutnya, yaitu di Kota Kupang, Kota Sama-rinda, Kota Sukabumi, Kota Bogor, Kota Kediri, Kota Mataram, Kota Palangkaraya dan pada Kabupaten Kupang, Kabupaten Belitung, Kabupaten Sukabumi, Kabupaten Bulungan, Kabupaten Serang, kabupaten Ogan Komering Ulu, dan Kabupaten Jeneponto. Pada tanggal 12 Juli 2005, pemerintah dengan Keputusan Presiden No. 18 Tahun 2005 membentuk BPSK di Kota Padang, Kabupaten Indramayu, Kabupaten Bandung, dan Kabupaten Tange-rang. Terakhir Pemerintah membentuk BPSK sebagaimana tertuang dalam Keputusan Presiden Nomor 23 Tahun 2006. Keputusan Presiden ini membentuk BPSK di Kota Pekalongan, Parepare, Pekanbaru, Denpasar,

\footnotetext{
${ }^{10}$ Di Indonesia dikenal Asas Nullun Delictum Nulla Poena Sine Praevia Lege Poenali atau asas Legalitas dimana asas ini mengandung arti tidak ada suatu perbuatan yang dapat dijatuhi pidana kecuali atas kekuatan peraturan pidana dalam Perundang-undangan yang telah ada sebelum perbuatan tersebut dilakukan.
}

Batam, Kabupaten Aceh Utara, dan Kabupaten Serdang Bedagai. Menurut ketentuan Pasal 90 Keppres No. 9 Tahun 2001, biaya pelaksanaan tugas BPSK dibebankan pada Anggaran Pendapatan dan Belanja Negara (APBN) dan Anggaran Pendapatan dan Belanja Daerah (APBD). Sebagai upaya untuk memudahkan konsumen menjangkau BPSK, maka dalam keputusan presiden tersebut, tidak dicantumkan pembatasan wilayah yurisdiksi BPSK, sehingga konsumen dapat mengadukan masalahnya pada BPSK mana saja yang dikehendakinya.

Keanggotaan BPSK diatur dalam Pasal 49 UUPK. Menurut Pasal 49 ayat (3) dan ayat (4) UUPK, keanggotaan BPSK terdiri dari 3 (tiga) unsur yaitu unsur pemerintah, unsur konsumen dan unsur pelaku usaha. Anggota setiap unsur berjumlah sekurang-kurangnya 3 (tiga) orang dan sebanyak-banyaknya 5 (lima) orang, sehingga jumlah anggota BPSK minimal 9 (sembilan) orang dan maksimal 15 (lima belas) orang. Sementara pengangkatan dan pemberhentian anggota BPSK ditetapkan oleh Menteri Perindustrian dan Perdagangan (saat sekarang kementerian ini di pisah menjadi 2 (dua) yaitu Kementerian Perindustrian dan Kementerian Perdagangan). Pasal 50 UUPK menjelaskan, setelah terpilih anggota BPSK, kemudian diisi struktur organisasi yang terdiri dari seorang ketua merangkap anggota, wakil ketua merangkap anggota dan anggota yang dalam pelaksanaan tugas di bantu oleh sekre-tariat yang terdiri dari kepala sekretariat dan anggota sekretariat. Pengangkatan dan pemberhentian sekretariat BPSK ditetapkan oleh menteri. UUPK memberikan persyaratan bahwa untuk dapat diangkat sebagai anggota BPSK harus memenuhi syarat umum dan syarat khusus (Pasal 6 Kepmenperindag No. 301/ MPP/ Kep/ 10/2001)

Tugas dan wewenang Badan Penyelesaian Sengketa Konsumen (BPSK) diatur pada Pasal 52 UUPK jo. SK. Menperindag Nomor 350/ MPP/ Kep/ 12/ 2001 tanggal 10 Desember 2001 tentang Pelaksanaan Tugas dan Wewenang Badan Penyelesaian Sengketa Konsumen, yaitu: (a) Melaksanakan penanganan dan penyelesaian sengketa konsumen dengan cara konsiliasi, mediasi, dan arbitrase; (b) Memberikan konsultasi 
perlindungan konsumen; (c) Melakukan pengawasan terhadap pencantuman klausula baku; (d) Melaporkan kepada penyidik umum jika terjadi pelanggaran Undang-Undang Perlindungan Konsumen (UUPK); (e) Menerima pengaduan tertulis maupun tidak dari konsumen tentang terjadinya pelanggaran terhadap perlindungan konsumen; (f) Melakukan penelitian dan pemeriksaan sengketa perlindungan konsumen; (g) Memanggil pelaku usaha yang diduga telah melakukan pelanggaran terhadap perlindungan konsumen; (h) Memanggil dan menghadirkan saksi, saksi ahli dan/atau setiap orang yang diduga mengetahui pelanggaran Undang-Undang Perlindungan Konsumen (UUPK); (i) Meminta bantuan kepada penyidik untuk menghadirkan saksi, saksi ahli, atau setiap orang pada butir $g$ dan butir $\mathrm{h}$ yang tidak bersedia memenuhi panggilan Badan Penyelesaian Sengketa Konsumen (BPSK); (j) Mendapatkan, meneliti dan/ atau menilai surat, dokumen, atau bukti lain guna penyelidikan dan/atau pemeriksaan; ( $k$ ) Memutuskan dan menetapkan ada tidaknya kerugian di pihak konsumen; (I) Memberitahukan putusan kepada pelaku usaha yang melakukan pelanggaran terhadap perlindungan konsumen; (m)Menjatuhkan sanksi administratif kepada pelaku usaha yang melanggar ketentuan UUPK.

Menunjuk pada Pasal 49 ayat (1) dan Pasal 54 ayat (1) UUPK jo. Pasal 2 SK Menperindag Nomor 350/MPP/Kep/12/2001, fungsi utama BPSK yaitu: sebagai instrumen hukum penyelesaian sengketa di luar pengadilan. Sedangkan tugas-tugas BPSK diatur pada Pasal 52 butir e, butir f, butir $g$, butir $h$, butir $i$, butir $j$, butir $k$, butir I dan butir m UUPK sebenarnya telah terserap dalam fungsi utama BPSK tersebut. Tugas BPSK memberikan konsultasi perlindungan konsumen (Pasal 52 butir b UUPK) dapat dipandang sebagai upaya sosialisasi UUPK, baik terhadap konsumen maupun pelaku usaha. Dalam hal konsultasi diberikan, jika suatu Permohonan Sengketa Konsumen (PSK) sudah terdaftar di Sekretariat BPSK, maka konsultasi yang diberikan BPSK tentu dalam rangka penyelesaian sengketa konsumen, baik dengan cara konsiliasi, mediasi, maupun arbitrase (Pasal 6 Kepmenperindag No. 301/ MPP/ Kep/ 10/2001).
Prosedur penyelesaian sengketa konsumen melalui BPSK ini terdiri dari tiga tahapan. Pertama, tahap permohonan yang meliputi persyaratan pengaduan penyelesaian penyelesaian sengketa tanpa pengacara; kedua, tahap persidangan yang dapat dilaksanakan dengan cara konsiliasi, mediasi dan arbitrase; dan ketiga, tahap putusan yang harus diselesaikan selambat-lambatnya 21 hari kerja terhitung sejak gugatan diterima yang dilanjutkan dengan eksekusi putusan. ${ }^{11}$

\section{Permasalahan-permasalahan dalam BPSK}

Suatu putusan badan peradilan tidak akan ada artinya, manakala tidak dapat dilaksanakan atau dieksekusi. Pada dasarnya suatu putusan yang sudah mempunyai kekuatan hukum yang pasti atau inkracht van gewijsde harus dapat dijalankan. Oleh karena itulah, putusan suatu badan peradilan harus mempunyai kekuatan eksekutorial, yaitu "kekuatan untuk dilaksanakan apa yang telah ditetapkan dalam putusan tersebut secara paksa oleh alat-alat negara.

Menurut Sudikno Mertokusumo, eksekusi atau pelaksanaan putusan dapat dibagi menjadi 2 jenis yaitu: eksekusi yang menghukum pihak yang kalah untuk membayar sejumlah uang (di atur dalam Pasal $195 \mathrm{HiR}$ atau Pasal $208 \mathrm{RBg}$ ); dan eksekusi putusan yang menghukum orang untuk melakukan suatu perbuatan (diatur dalam Pasal $225 \mathrm{HiR}$ atau Pasal 259 RBg). Kemudian eksekusi riil untuk memerintahkan pengosongan benda tetap, diatur Pasal 1033 RV. ${ }^{12}$

Adapun yang memberi kekuatan eksekutorial atau yang menjadi persyaratan pada suatu putusan untuk dapat dilaksanakan secara paksa baik putusan pengadilan maupun putusan arbitrase harus memuat kepala putusan atau disebut irah-irah yang berbunyi “Demi Keadilan

\footnotetext{
${ }^{11}$ Kurniawan dan Abdul Wahab, "Tinjauan Yuridis Terhadap Prosedur Penyelesaian Sengketa Konsumen Melalui BPSK di Indonesia", J urnal Hukum J atiswara, Fakultas Hukum Universitas Mataram, Vol. 23, No. 2, J uli 2008. hlm. 54.

12 Sudikno Mertokusumo dalam Muhammad Jailani, "Faktorfaktor Yang Mempengaruhi dan Menghambat pelaksanaan Putusan Hakim (eksekusi) dalam Perkara Perdata", Majalah IImiah IImu Hukum Jatiswara, Terakreditasi DirjenDikti No. 34/Dikti/Kep/2003, Fakultas Hukum Universitas Mataram, Vol. 20, No. 3, Juli 2005, hlm. 336337.
} 
Berdasarkan Ketuhanan Yang Maha Esa". Kepala putusan inilah yang memberi kekuatan eksekutorial terhadap suatu putusan. ${ }^{13}$ Bahkan tidak hanya putusan pengadilan dan putusan arbitrase yang harus mencantumkan irah-irah atau kepala putusan, akan tetapi akte notaris seperti grose akta hipotik (grose akta van hypotheek) dan grose akta pengakuan hutang (notarieele schuld-brieven) harus mencantumkan kepala putusan "Demi Keadilan Berdasarkan Ketuhanan Yang Maha Esa". Kepala akta tersebut merupakan syarat yang mesti ada agar kata notariil di muka memiliki nilai kekuatan sama dengan putusan pengadilan yang telah memperoleh kekuatan hukum tetap atau inkrah. ${ }^{14}$ Eman Suparman juga menjelaskan, selain dimiliki oleh putusan pengadilan, putusan arbitrase dan grose akta notariil, kepala putusan atau irahirah juga dimiliki oleh akta perdamaian sebagaimana diatur dalam Pasal 130 ayat (2) HIR yang dibuat dipersidangan juga mempunyai kekuatan untuk dilaksanakan seperti putusan yang telah memperoleh kekuatan hukum tetap. ${ }^{15}$

Permohonan eksekusi dapat dilakukan baik terhadap putusan BPSK maupun putusan keberatan, namun UUPK tidak menyediakan peraturan yang lebih rinci berkaitan dengan hal tersebut. Pelaksanaan putusan arbitrase diserahkan dan menjadi wewenang penuh dari Pengadilan Negeri yang menjalankan fungsi kekuasaan kehakiman, dan mempunyai legitimasi sebagai lembaga pemaksa. Adapun tata cara melaksanakan putusan Hakim diatur dalam Pasal 195 sampai dengan Pasal 208 HIR. Ketentuan mengenai prosedur permohonan eksekusi tidak diatur secara rinci dan jelas dalam UUPK. Pasal 57 UUPK menjelaskan bahwa putusan majelis dimintakan penetapan eksekusinya kepada Pengadilan Negeri di tempat konsumen dirugi-

\footnotetext{
${ }^{13}$ Ketentuan mengenai irah-irah atau kepala putusan untuk lembaga peradilan dapat dilihat pada Pasal 4 ayat (1) UU Nomor 35 Tahun 1999 jo. Undang-Undang No. 4 Tahun 2004 tentang Kekuasaan Kehakiman, sedangkan untuk ketentuan irah-irak untuk arbitase diatur dalam Paal 54 UU Nomor 30 Tahun 1999 tentang Arbitrase dan APS.

${ }^{14}$ Eman Suparman, 2004, Pilihan Forum Arbitrase dalam Sengketa Komersial untuk Penegakan Keadilan. J akarta: PT. Tatanusa, hlm. 198-199

$15 \mathrm{Ibid}$
}

kan. Kemudian ketentuan Pasal 57 UUPK ini diperjelas dengan Pasal 42 Kepmenperindag No. 350/ MPP/ 12/ 2001 bahwa pihak yang mengajukan eksekusi adalah BPSK.

Pada putusan arbitrase BPSK, terdapat kendala dalam pelaksanaan permohonan eksekusi yang disebabkan tidak adanya pencantuman irah-irah pada putusan arbitase BPSK tersebut. Hal ini berbeda dengan isi suatu putusan arbitrase yang dalam putusannya mengandung irah-irah. Pasal 54 Ayat (1) butir a Undang-Undang No. 30 Tahun 1999 tentang Arbitrase dan APS, menyatakan suatu putusan arbitrase harus memuat kepala putusan atau irah-irah "Demi Keadilan Berdasarkan Ketuhanan Yang Maha Esa". Ketentuan Pasal 57 UUPK bertentangan dengan Pasal 4 Ayat (1) Undang-Undang No. 14 tahun 1970 yang telah diubah dengan UndangUndang No. 4 Tahun 2004 tentang Kekuasaan Kehakiman, bahwa suatu putusan harus memuat irah-irah "Demi Keadilan Berdasarkan Ketuhanan yang Maha Esa". Pencantuman irahirah ini memberikan kekuatan eksekutorial pada putusan tersebut sehingga penghapusan irah-irah mengakibatkan putusan menjadi batal demi hukum.

Sebagai suatu contoh kasus, BPSK Kota Bandung pernah mengajukan fiat eksekusi terhadap putusan BPSK Nomor 66/ Pts-BPSK/VII/ 2005 ke Pengadilan Negeri Jakarta Pusat, namun Pengadilan Negeri J akarta Pusat menyatakan bahwa putusan BPSK tidak dapat dieksekusi karena tidak mempunyai irah-irah, padahal dalam putusan BPSK, tidak dikenal adanya irahirah. ${ }^{16}$ Pengadilan Negeri J akarta Pusat melalui Surat Nomor W7.Db.Ht.04.10.3453.2005 memberikan tanggapan terhadap permohonan penetapan eksekusi putusan BPSK Kota Bandung yang pada intinya menyatakan bahwa permohonan pelaksanaan eksekusi putusan BPSK belum dapat diproses karena belum memenuhi beberapa syarat yaitu: Bahwa sesuai dengan UU No. 30 Tahun 1999 tentang Arbitrase dan APS dalam Pasal 54 ayat (1) bahwa Putusan Arbitra-

\footnotetext{
${ }^{16}$ Tim pembuatan PERMA Tata Cara Pengajuan Keberatan terhadap Putusan BPSK, lebih jelas lihat Susanti Adi Nugroho, 2008, Proses Penyelesaian Sengketa Konsumen Di Tinjau dari Hukum Acara serta Kendala Implementasinya, J akarta: Kencana, hlm. 341
} 
se Penyelesaian Sengketa harus memuat kepala putusan yang berbunyi "DEMI KEADILAN BERDASARKAN KETUHANAN YANG MAHA ESA", dan merujuk ketentuan tersebut, sebagaimana diatur dalam Bab $\mathrm{V}$ pelaksanaan putusan arbitrase nasional bagian pertama Pasal 59 yaitu: (1) Dalam waktu paling lama 30 (tiga puluh) hari terhitung sejak tanggal putusan diucapkan, lembar asli atau salinan otentik Putusan Arbitrase diserahkan dan didaftarkan oleh arbiter atau kuasanya kepada Pengadilan Negeri; (2) Penyerahan dan pendaftaran sebagaimana dimaksud dalam ayat (1) dilakukan dengan pencatatan dan penandatangan pada bagian akhir atau dipinggir putusan oleh panitera Pengadilan negeri dan arbiter atau kuasanya yang menyerahkan, dan catatan tersebut merupakan akta pendaftaran; (3) Arbiter atau kuasanya wajib menyerahkan putusan dan lembar asli pengangkatan arbiter atau salinan otentiknya kepada Panitera Pengadilan Negeri.

UUPK maupun SK Menperindag Nomor 350/ MPP/ Kep/ 12/ 2001 yang mengatur tentang pelaksanaan tugas dan wewenang lembaga BPSK, tidak mengatur mengenai kewajiban pencantuman irah-irah pada putusan BPSK. Hal ini disebabkan kedudukan BPSK yang secara struktural berada di bawah Departemen (baca: Kementerian) Perdagangan, sedangkan HIR/ RBg dan Undang-Undang Kekuasaan Kehakiman merupakan peraturan yang berlaku bagi badan peradilan. Penulis berpendapat, sebenarnya persoalannya bukan pada BPSK dibawah Departemen Perdagangan atau Kementerian mana, melainkan bahwa BPSK melaksanakan penanganan dan penyelesaian sengketa konsumen dengan cara arbitrase, sehingga mengandung konsekuensi bahwa putusan arbitrase juga harus dicantumkan irah-irah atau kepala putusan "Demi Keadilan Berdasarkan KeTuhahan Yang Maha Esa" sebagaimana ketentuan dalam UU No. 30 Tahun 1999 tentang Arbitrase dan APS sebagai ketentuan khusus yang mengatur mengenai Arbitrase di Indonesia. Pasal 48 UUPK menyatakan "penyelesaian sengketa konsumen melalui pengadilan mengacu pada ketentuan tentang peradilan umum yang berlaku dengan memperhatikan ketentuan dalam Pasal 45 UU-
PK." Sedangkan Pasal 45 UUPK secara garis besar menyatakan bahwa penyelesaian sengketa konsumen dapat ditempuh melalui pengadilan ataupun di luar pengadilan. Penyelesaian di luar pengadilan ini yang dilaksanakan dengan konsiliasi, mediasi dan arbitrase. Atas pendekatan inilah, maka permohonan eksekusi putusan BPSK berda-sarkan ketentuan Pasal 57 UUPK jo. Pasal 42 SK Menperindag Nomor 350/ MPP/ Kep/ 12/ 2001 dapat dilaksanakan karena merupakan kekhususan dari pelaksanaan eksekusi secara umum menurut ketentuan hukum acara perdata sesuai dengan asas hukum lex specialis derogat legi generalis yang berarti bahwa ketentuan khusus menyampingkan ketentuan yang bersifat umum. ${ }^{17}$

Menjadi sebuah pertanyaan berkaitan dengan pertentangan antara Pasal 57 UUPK jo. Pasal 42 SK Menperindag No. 350/ MPP/ Kep/ 12/ 2001 dengan ketentuan hukum acara perdata pada umumnya mengenai lembaga BPSK yang harus mengajukan permohonan eksekusi ke pengadilan atas putusan yang dihasilkannya, bukan pihak yang dimenangkan. BPSK merupakan lembaga yang menyelesaikan sengketa konsumen, di mana ia memiliki kewajiban untuk memutus sengketa antara konsumen dan pelaku usaha dalam menetapkan kerugiannya, oleh karena itu, kedudukan BPSK harus netral dan tidak berpihak sehingga memberikan keseimbangan antara kepentingan konsumen, dan pelaku usaha/ produsen. Meskipun tujuan utama pendirian BPSK adalah untuk memberikan perlindungan hukum terhadap konsumen, tetapi ini tidak berarti bahwa dalam upaya pelaksanaan ganti kerugian, BPSK yang harus mengajukan per-mohonan eksekusinya ke pengadilan. Oleh karena ganti kerugian diberikan untuk kepentingan konsumen, maka yang dapat mengajukan eksekusi terhadap putusan BPSK hanyalah konsumen sendiri, bukan lembaga BPSK.

Apabila BPSK dikenakan kewajiban untuk mengajukan eksekusi seperti yang ditentukan dalam Pasal 57 UUPK jo. Pasal 42 SK Menperindag No. 350/ MPP/ Kep/ 12/2001, maka kedudukan BPSK sebagai badan yang netral dan impar-

\footnotetext{
${ }^{17} \mathrm{Ibid}$
} 
sial menjadi diragukan. Selain itu, apabila BPSK melakukan pengajuan permohonan eksekusi, maka akan menambah beban kerja dari BPSK itu sendiri. Untuk itulah, dengan adanya ketentuan Pasal 7 Ayat (1) PERMA No. 1 Tahun 2006 yang menegaskan bahwa "pengadilan mengeluarkan penetapan eksekusi atas permintaan pihak yang berperkara (konsumen) atas putusan BPSK yang tidak diajukan keberatan", dapat mendorong kinerja BPSK yang lebih baik. Menurut penulis, apabila dikaitkan dengan asas hukum, maka ketentuan Pasal 7 ayat (1) PERMA No. 1 Tahun 2006 sebenarnya tidak bisa dijadikan dasar hukum atau pegangan dalam menjelasakan pihak mana yang berhak mengajukan eksekusi, hal ini disebabkan karena ketentuan Pasal 7 ayat (1) PERMA No. 1 Tahun 2006 bertentangan dengan Pasal 57 jo. Pasal Pasal 42 SK Menperindag No. 350/ MPP/ Kep/12/ 2001. Menurut asas hukum yang berlaku yaitu lex superior legi imperior atau ketentuan yang lebih tinggi mengalahkan ketentuan yang lebih rendah, maka dengan sendirinya PERMA No. 1 Tahun 2006 ini tidak bisa dijadikan patokan atau dasar karena dikalahkan oleh aturan yang lebih tinggi yaitu Pasal 57 UUPK. Eksekusi terhadap putusan arbitrase BPSK seharusnya memperhatikan ketentuan Undang-undang No. 30 Tahun 1999 dan Hukum Acara Perdata yang berlaku. Pemilihan arbitrase dalam penyelesaian sengketa melalui BPSK, menjadikan BPSK menjadi suatu lembaga arbitrase dan untuk itu harus memperhatikan ketentuan arbitrase nasional. Tata cara eksekusi yang dilakukan setelah penetapan eksekusi diberikan menyangkut ketentuan dalam HIR/ RBg sebagai induk peraturan dalam Hukum Acara Perdata, karena sengketa antara konsumen dengan pelaku usaha yang diselesaikan melalui jalur arbitrase juga merupakan ranah hukum perdata.

\section{Kendala-kendala dalam BPSK}

Pengadilan merupakan salah satu institusi untuk mengupayakan supremasi hukum yang merupakan salah satu ciri dari negara hukum. Perselisihan antara pelaku usaha dengan konsumen dapat diselesaikan melalui Pengadilan Negeri. Tetapi setidaknya upaya non litigasi, bisa menjadi alternatif untuk menyelesaikan perselisihan antara pihak-pihak yang bersengketa. Penggunaan salah satu jalur penyelesaian sengketa dipengaruhi oleh konsep tuj uan, ketajaman cara berfikir, serta budaya sosial masyarakat. Penggunaan model penyelesaian sengketa non-litigasi lebih mengutamakan pendekatan "konsensus" dan berusaha mempertemukan kepentingan pihak-pihak yang bersengketa serta bertujuan mendapatkan hasil penyelesaian ke arah win-win solution, sehingga keadilan yang ingin dicapai melalui mekanisme non-litigasi ini adalah keadilan komutatif. ${ }^{18}$

Menurut Erman Rajagukguk, budaya hukum masyarakat termasuk faktor yang mempengaruhi arti penting penyelesaian sengketa bisnis di luar pengadilan. Budaya tradisional yang menekankan kepada komunitas, kekerabatan, harmoni, primus inter pares telah mendorong penyelesaian sengketa di luar pengadilan yang formal. Demikian budaya yang menekankan kepada efisiensi dan efektifitas sama kuatnya mendorong penye-lesaian sengketa bisnis tanpa melalui pengadilan. ${ }^{19}$

Keberadaan BPSK diharapkan menjadi alternatif bagi kejenuhan dan keperihatinan masyarakat terhadap sistem peradilan di Indonesia. Namun, ternyata UUPK tidak secara tuntas memberikan peran kepada BPSK sebagai suatu lembaga alternatif penyelesaian sengketa konsumen. Ada beberapa persoalan yang dihadapi dalam praktik, yaitu menyangkut eksistensi dari lembaga BPSK. Persoalan lainnya yang krusial adalah menyangkut tugas dan kewenangan BPSK. Ketentuan Pasal 54 ayat (3) UUPK bahwa putusan BPSK bersifat "final dan mengikat" kehilangan makna dan menjadi tidak berarti bagi konsumen yang mencari keadilan melalui BPSK, ketika dihadapkan dengan ketentuan Pasal 56 ayat (2) dimana terbukanya peluang mengajukan keberatan ke Pengadilan Negeri. Padahal dalah sistem hukum acara di Indonesia, baik

\footnotetext{
${ }^{18}$ Adi Sulistiyono, "Budaya Musyawarah Untuk Penyelesaian Sengketa Win-Win Solution Dalam Perspektif Hukum", J urnal Hukum Bisnis, Volume 25 No. 1, tahun 2006, hlm. 72.

${ }^{19}$ Erman Rajagukguk, "Budaya Hukum dan Penyelesaian Sengketa Perdata di Luar Pengadilan", Jurnal Magister Hukum, PPs-Ull, Yogyakarya, Volume. 2 No. 4, Oktober 2000. hlm. 7
} 
hukum acara pidana maupun hukum acara perdata tidak mengenal istilah keberatan. Terminologi keberatan hanya dikenal dalam hukum administrasi negara yang disebut sebagai administrative beroef system dan dalam hukum acara PTUN digunakan sebagai upaya hukum terhadap putusan pejabat Tata Usaha Negara. ${ }^{20} \mathrm{Da}$ lam proses pengajuan keberatan terhadap putusan BPSK, muncul permasalahan mengenai bagaimana pengadilan harus memperlakukan keberatan atas putusan BPSK tersebut. Hal ini tampak dari beberapa pengajuan keberatan atas putusan BPSK yang didasarkan atas beberapa alasan, antara lain: BPSK salah menerapkan hukum acara sehingga hukum formal, konsumen sebagai penggugat telah salah menggugat (error in persona), BPSK dianggap salah menjatuhkan putusan, keberatan ditafsirkan sebagai gugatan oleh Pengadilan Negeri sehingga membawa BPSK sebagai tergugat, atau keberatan ditafsirkan sebagai upaya hukum banding. ${ }^{21}$ Terhadap permasalahan ini, Mahkamah Agung RI mengeluarkan PERMA No. 1 Tahun 2006 tentang Tata Cara Penggunaan Upaya Hukum Keberatan Terhadap Putusan BPSK. Mahkamah Agung menetapkan bahwa keberatan merupakan upaya hukum yang hanya dapat diajukan terhadap putusan arbitrase yang dikeluarkan BPSK, tidak meliputi putusan BPSK yang timbul dari mediasi dan konsiliasi. Putusan mediasi dan konsiliasi dapat disepadankan dengan adanya suatu perdamaian (dading) di luar pengadilan atau di dalam pengadilan sehingga putusannya bersifat final dan mengikat. ${ }^{22}$ Namun tetap saja keluarnya PERMA ini belum dapat menyelesaikan perso-alan upaya "keberatan" ini. Selain itu, ketentuan Pasal 57 UUPK mengenai permintaan eksekusi putusan BPSK kepada Pengadilan Negeri di tempat konsumen yang dirugikan membawa persoalan hukum yang sa-

\footnotetext{
${ }^{20}$ Bernadette T. Wulandari, "Badan Penyelesaian Sengketa Konsumen (BPSK) Sebagai Alternatif Upaya Penegakan Hak Konsumen di Indonesia", J urnal Gloria J uris, Fakultas Hukum Unika Atma Jaya, Jakarta, Volume 6, Nomor 2. Mei-Agustus 2006, hlm. 147

${ }^{21}$ lbid.

${ }^{22}$ Maslihat Nur Hidayati, "Analisis Tentang Alternatif Penyelesaian Sengketa Konsumen: Studi Tentang Efektifitas Badan Penyelesaian Sengketa Perlindungan Konsumen", J urnal Hukum Lex Jurnalica, Universitas Indonusa Esa Unggul, Volume 5 No. 3 Tahun 2008, hlm. 175-176.
}

ngat luas, misalnya mengenai pengajuan permohonan eksekusi serta tata cara mengajukan upaya keberatan ke Pengadilan Negeri.

Berikut ini dikemukakan beberapa kelemahan dari UUPK berkaitan dengan keberadaan BPSK, yaitu antara lain sebagai berikut. ${ }^{23}$ Pertama, peluang untuk mengajukan keberatan terhadap putusan BPSK ke Pengadilan Negeri; kedua, tidak jelas tugas dan kewenangan BPSK; ketiga, tidak adanya pengaturan jika pelaku usaha selaku tergugat di BPSK tidak memenuhi panggilan meski telah dipanggil secara patut; keempat, UUPK menugaskan BPSK untuk melakukan pengawasan pencantuman klausula baku; kelima, tidak adanya perlindungan bagi anggota BPSK; dan keenam, belum adanya keseragaman honor BPSK se-Indonesia yang diatur dalam APBN, sementara biaya operasional dibebankan pada APBD Kabupaten/ Kota.

Susanti Adi Nugroho (Hakim Agung Republik Indonesia) berpen-dapat bahwa ada beberapa kendala/kelemahan sehingga BPSK selama ini tidak dapat berjalan dengan optimal. Kendala-kendala atau kelemahan tersebut antara lain, pertama, kendala kelembagaan; kedua, kendala pendanaan; ketiga, kendala sumber daya manusia BPSK; keempat, kendala peraturan; kelima, kendala pembinaan dan pengawasan, dan minimnya koordinasi antar aparat penanggung jawab; kelima, kurangnya sosialisasi dan rendahnya kesadaran hukum konsumen; keenam, kurangnya respon dan pemahaman dari badan peradilan terhadap kebijakan perlindungan konsumen; dan ketujuh, kurangnya respon masyarakat terhadap UU Perlindungan Konsumen dan lembaga BPSK. ${ }^{24}$

Mas Achmad Sentosa menilai problem atau masalah besar yang dihadapi oleh BPSK adalah peran-nya yang terlalu berat sehingga sulit menjalankan perannya tersebut secara efektif. UUPK menjelaskan terdapat 5 (lima) peran yang dibebankan pada BPSK, yaitu: pertama, peran sebagai penyedia jasa penyelesaian sengketa sebagai mediator, konsiliator, arbi-

\footnotetext{
${ }^{23}$ Suherdi Sukandi, 6 November 2008, UUPK, Strategis Bagi Pergerakan Perlindungan Konsumen, BPSK Kota Bandung, tersedia di website www.google.com, diakses tanggal. 19 Desember 2009.

${ }^{24}$ Susanti Adi Nugroho, op.cit, hlm. 234-235.
} 
ter; kedua, peran konsultan masyarakat atau public defender; ketiga, peran administrative regulator sebagai pengawas dan pemberi sanksi; keempat, peran ombudsman serta; dan kelima, peran ajudicator atau pemutus. ${ }^{25}$ Kelima peran yang dibebankan pada BPSK ini tidak diimbangi dengan Sumber Daya Manusia (SDM) yang mampu untuk mengemban tugas yang diberikan. Selain itu peran-peran tersebut juga berpotensi menimbulkan pertentangan kepentingan. Misalnya, peran mediator yang membutuhkan peran netral, dengan regulator, atau peran mediator dengan ajudicator.

Penulis sependapat, sebaiknya ke depan BPSK diberikan tugas khusus untuk menyelesaikan sengketa konsumen dengan pelaku usaha, sedangkan tugas lain seperti pengawasan terhadap klausula baku menjadi tugas dari Badan Perlindungan Konsumen Nasional (BPKN). Berkaitan dengan amandemen UUPK, terdapat beberapa hal penting yang diusulkan penulis.

Pertama, pembatasan atau pengurangan tugas BPSK. Tugas BPSK sebagaimana diatur dalam Pasal 52 UUPK jo. SK. Menperindag Nomor 350/ MPP/ Kep/ 12/ 2001 adalah: (a) Melaksanakan penanganan dan penyelesaian sengketa konsumen dengan cara konsiliasi, mediasi, dan arbitrase; (b) Memberikan konsultasi perlindungan konsumen; (c) Melakukan pengawasan terhadap pencantuman klausula baku; (d) Melaporkan kepada penyidik umum jika terjadi pelanggaran Undang-Undang Perlindungan Konsumen (UUPK); (e) Menerima pengaduan tertulis maupun tidak dari konsumen tentang terjadinya pelanggaran terhadap perlindungan konsumen; (f) Melakukan penelitian dan pemeriksaan sengketa perlindungan konsumen; $(\mathrm{g})$ Memanggil pelaku usaha yang diduga telah melakukan pelanggaran terhadap perlindungan konsumen; (h) Memanggil dan menghadirkan saksi, saksi ahli dan/atau setiap orang yang diduga mengetahui pelanggaran Undang-Undang Perlindungan Konsumen (UUPK); (i) Meminta bantuan kepada penyidik untuk menghadirkan saksi, saksi ahli, atau se-tiap orang pada butir $g$ dan butir $h$ yang

\footnotetext{
${ }^{25}$ Mas Achmad Sentosa, 20 J uli 2005, Peranan BPSK Terlalu Berat, tersedia di website www.hukumonline.com, diakses tanggal 5 Oktober 2009.
}

tidak bersedia memenuhi panggilan Badan Penyelesaian Sengketa Konsumen (BPSK); (j) Mendapatkan, meneliti dan/atau menilai surat, dokumen, atau bukti lain guna penyelidikan dan/ atau pemeriksaan; ( $k$ ) Memutuskan dan menetapkan ada tidaknya kerugian di pihak konsumen; (I) Memberitahukan putusan kepada pelaku usaha yang melakukan pelanggaran terhadap perlindungan konsumen; (m) Menjatuhkan sanksi administratif kepada pelaku usaha yang melanggar ketentuan Undang-Undang Perlindungan Konsumen (UUPK).

Tugas ini terlalu berat dan kompleks oleh BPSK, sehingga BPSK ke depan hendaknya dibatasi tugasnya hanya menyelesaikan sengketa konsumen tanpa dibebani tugas lainnya. Hal ini dimaksudkan agar BPSK benar-benar fokus dalam melaksanakan tugasnya dengan baik dan juga sesuai dengan namanya yaitu Badan Penyelesaian Sengketa Konsumen artinya tugas utamanya adalah menyelesaikan sengketa yang terjadi antara konsumen dengan pelaku usaha. Sedangkan tugas-tugas lain sebaiknya dibebankan pada Badan Perlindungan Konsumen Nasional (BPKN). BPSK yang diposisikan menjalankan multi peran yang sangat kompleks dalam penegakan hukum perlindungan konsumen (Pasal 52 UUPK) akan sangat sulit menjalankan perannya dengan efektif dikarenakan faktor-faktor berikut: ${ }^{26}$ (a) Peran yang dimiliki terlalu berat yang mencakup peran dispute settlement service pro-vider (mediator, konsiliator dan arbitrator), konsultan masyarakat/ public defender, admi-nistratif regulator (pengawas dan pemberi sanksi), ombudsman, dan adjudicator. Andai katapun BPSK dilaksanakan dengan cara membentuk multidoors (dengan membagi bidangbidang berdasarkan peran-peran tersebut), maka akan sulit dilaksanakan karena peran-peran tersebut membutuhkan SDM yang highly skills, dimana saat ini sangat sulit dikembangkan di tingkat kota/ kabupaten; (b) Diantara peran-peran tersebut apabila dilaksanakan sangat berpotensi terjadi pertentangan kepentingan (conflict of interest), sebagai contoh antara peran mediator (yang membutuhkan peran netral)

\footnotetext{
${ }^{26}$ Kurniawan dan Abdul Wahab, op.cit.
} 
dan regulator (penegak hukum), mediator (penengah) dan adjudicator (pemutus), serta public defender (advocate masyarakat) dengan adjudicator (mensyaratkan peran netral dan imparsial).

Kedua, dukungan dana yang optimal pada BPSK. Salah satu faktor yang menyebabkan BPSK tidak berjalan optimal adalah karena kurangnya dukungan dana dari pemerintah pusat maupun daerah. Pasal 3 Keppres No. 90 tahun 2001 tentang Pembentukan BPSK pada Pemerintah Kota Medan, Kota Palembang, Kota Jakarta Pusat, Kota J akarta Barat, Kota Bandung, Kota Semarang, Kota Yogyakarta, Kota Surabaya, Kota Malang dan Kota Makassar mengemukakan "biaya pelaksanaan tugas BPSK dibebankan kepada Anggaran Pendapatan Negara (APBN) dan Anggaran Pendapatan Belanja Daerah (APBD)". Pembagian alokasi anggaran dana ini adalah untuk honor anggota/ sekretariat BPSK dibebankan pada APBN, sementara biaya operasional dibebankan pada APBD Kabupaten/Kota masing-masing. Hanya saja mengenai besarannya alokasi anggaran ini tidak diatur dengan jelas dan rinci.

Persoalan yang juga muncul adalah menyangkut kesiapan dan alokasi dana APBD dari masing-masing daerah yang tidak maksimal terhadap BPSK, partisipasi daerah selama ini dalam pemberian alokasi dana untuk efektivitas BPSK masih minim, hal ini sangat mempengaruhi kinerja dari BPSK selama ini di daerah. Ke depan, persoalan alokasi pendanaan untuk BPSK harus diatur dengan jelas dan rinci artinya pendanaan dari APBN presentasenya jelas, demikian juga pendanaan dari APBD harus ditingkatkan. J angan sampai masalah honor saja tidak ada kesamaan atau terjadi perbedaan antara BPSK di daerah yang satu dengan daerah yang lain, karena hal ini akan menyebabkan kecemburuan antar kelembagaan BPSK di daerah yang satu dengan daerah yang lain sendiri.

Lahirnya UUPK diharapkan mampu memberikan solusi bagi konsumen dalam menyelesaikan persoalan-persoalan yang terjadi, ternyata selama ini dalam penegakan hukum perlindungan konsumen masih terjadi ketimpangan dan menimbulkan kebingungan bagi konsumen, hal ini terjadi manakala masuknya peran lembaga pengadilan dalam memeriksa perkara "keberatan" atas putusan BPSK yang sudah bersifat final dan mengikat, kemudian pelaksanaan eksekusi yang harus melalui pengadilan, dan upaya hukum kasasi atas putusan Pengadilan Negeri yang memeriksa perkara keberatan atas putusan BPSK. Ke depan, agar BPSK bekerja dengan optimal dan konsumen maupun pelaku usaha mendapatkan kepastian hukum dalam penyelesaian sengketa, maka harus dipisahkan antara penyelesaian sengketa melalui litigasi (pengadilan) dan penyelesaian sengketa melalui BPSK. Apabila konsumen sudah memilih jalur BPSK untuk menyelesaian sengketanya, maka kewenangan penuh harus diberikan kepada BPSK untuk menyelesaikan sengketa konsumen tersebut dengan putusan BPSK yang final dan mengikat serta dapat di eksekusi langsung, tanpa kemudian diberikan kesempatan pada badan peradilan (Pengadilan Negeri) untuk masuk di tengah jalan menyelesaikan sengketa konsumen yang sudah berjalan. Hal ini dimaksudkan agar konsumen maupun pelaku usaha mendapatkan kepastian hukum dalam penyelesaian sengketa konsumen dan tidak memakan waktu yang lama sehingga ada perbedaan antara penyelesaian sengketa melalui pengadilan dengan penyelesaian melalui BPSK.

Ketiga, Penyempurnaan Kelembagaan BPSK. UUPK menjelaskan bahwa terdapat 4 (empat) komponen pengawal dan penegak hukum perlindungan konsumen di Indonesia yaitu pemerintah (Direktorat Perlindungan Konsu-men), Badan Perlindungan Konsumen Nasional (BPKN), Badan Penyelesaian Sengketa Konsumen (BPSK) dan Lembaga Perlindungan Konsumen Swadaya Masyarakat (LPKSM). Tanggungj awab penegakan hukum perlindungan konsumen yang berada pada berbagai lembaga ini menyebabkan terjadi tumpang tindih tugas dan kewenangan antara lembaga yang satu dengan lembaga yang lain dan kurang terjalin koordinasi antar lembaga ini, misalnya pemerintah (Direktorat Perlindungan Konsumen) oleh UUPK diberikan kewenangan untuk menyelesaikan sengketa konsumen, padahal tugas ini merupakan kewenangan dari BPSK. Ke depan diperlukan keje- 
Iasan tugas dan kewenangan serta koordinasi langkah penegakan hukum antar lembaga-lembaga pengawal dan penegak hukum perlindungan konsumen tersebut. Sehingga penerapan UUPK maupun peraturan perundang-undangan lainnya di bidang perlindungan konsumen dapat dilaksanakan secara efektif.

Selain persoalan-persoalan di atas, revisi UUPK harus memperhatikan perihal sosialisasi keberadaan BPSK. Saat ini, keberadaan UUPK khususnya BPSK yang sudah 10 (sepuluh) tahun ternyata belum banyak diketahui oleh masyarakat umum. Untuk mengatasi persoalan ini, maka ke depan perlu dilakukan upaya-upaya yang sistematis dalam sosialisasi keberadaan BPSK sebagai lembaga yang menyelesaikan persoalan konsumen di luar pengadilan. Adapun upaya-upaya yang harus dilakukan adalah memperbanyak kampanye perlindungan konsumen khususnya keberadaan BPSK dan memberikan pendidikan kepada konsumen sejak usia dini.

\section{Penutup Simpulan}

Berdasarkan penjelasan di atas, ada beberapa simpulan yang berkaitan dengan permasalahan yang dihadapi dalam praktik menyangkut eksistensi dari lembaga BPSK. Pertama, berkaitan dengan eksistensi BPSK sebagai lembaga yang masuk dalam domain pemerintah pusat ataukah pemerintah daerah. Jawaban terhadap hal ini dalam prakteknya tidak sama. Oleh karena itu, ada BPSK yang mendapat dukungan penuh dari pemerintah daerah dan ada BPSK yang kurang mendapat dukungan Pemerintah Daerah. Kedua, persoalan yang krusial adalah menyangkut tugas dan kewenangan BPSK. Ketentuan Pasal 54 ayat (3) UUPK bahwa putusan BPSK bersifat "final dan mengikat". Putusan ini menjadi kehilangan makna dan menjadi tidak berarti bagi konsumen yang mencari keadilan melalui BPSK, ketika dihadapkan dengan ketentuan Pasal 56 ayat (2) dimana terbukanya peluang mengajukan keberatan ke Pengadilan Negeri, dan ketentuan Pasal 57 UUPK mengenai permintaan eksekusi putusan BPSK kepada Pengadilan Negeri di tempat konsumen yang dirugikan. Adapun kendala-kendala yang dihadapi
BPSK adalah kendala kelembagaan, keuangan, SDM, peraturan, pembinaan dan pengawasan dan kurangnya sosialisasi serta rendahnya kesadaran hukum konsumen.

Berkaitan dengan kendala dalam pelaksanaan putusan arbitrase BPSK, dapat disimpulkan bahwa terdapat kendala dalam pelaksanaan permohonan eksekusi yang disebabkan tidak adanya pencantuman irah-irah pada putusan arbitase BPSK tersebut. Hal ini berbeda dengan putusan arbitrase menurut Pasal 54 Ayat (1) butir a UU No. 30 Tahun 1999 tentang Arbitrase dan Alternatif Penyelesaian Sengketa (APS) yang menyatakan suatu putusan arbitrase harus memuat kepala putusan atau irah-irah yang berupa "Demi Keadilan Berdasarkan Ketuhanan Yang Maha Esa".

\section{Saran}

Berdasarkan pembahasan atas beberapa persoalan yang ada dalam UUPK, maka penulis menyarankan agar segera dilakukan revisi UUPK agar ke depan lebih memberikan kepastian hukum pada konsumen maupun pelaku usaha. Salah satu revisi adalah dengan mencantumkan irah-irah "Demi Keadilan Berdasarkan Ketuhanan Yang Maha Esa". Pemerintah hendaknya memperkuat Sumber Daya Manusia (SDM) pada sekretariat BPSK mengingat tugas-tugas dari BPSK yang begitu luas. Di samping itu pemerintah juga hendaknya memberikan anggaran yang cukup pada BPSK karena salah satu kendala pelaksanaan tugas BPSK adalah karena faktor anggaran.

\section{Daftar Pustaka}

Barkatullah, Abdul Halim. "Urgensi Perlindungan Konsumen Dalam Transaksi di E-Commerce". Jurnal Hukum, No. 2 Vol. 14 April 2007. FH UII Yogyakarta:

Gunawan, J ohannes. "Pemberlakuan Undangundang Perlindungan Konsumen Terhadap PT. PLN Sebagai Lembaga Pelayanan Umum". Pro Justitia, Jurnal Hukum Triwulan Tahun 19, Nomor 4, Oktober 2001. Universitas Katolik Parahyangan;

Hartono, Sri Redjeki. "Perlindungan Konsumen di Indonesia (Tinjauan Makro)". Jurnal 
Mimbar Hukum, Edisi Khusus No. 39/ X/ 2001. FH UGM;

Hidayati, Maslihat Nur. "Analisis Tentang Alternatif Penyelesaian Sengketa Konsumen: Studi Tentang Efektifitas Badan Penyelesaian Sengketa Perlindungan Konsumen". J urnal Hukum Lex J urnalica, Vol 5 No.3 Tahun 2008. Universitas Indonusa Esa Unggul;

Jailani, Muhammad. "Faktor-faktor Yang Mempengaruhi dan Menghambat pelaksanaan Putusan Hakim (eksekusi) dalam Perkara Perdata". Majalah IImiah IImu Hukum Jatiswara, Vol. 20, No. 3, Juli 2005. Fakultas Hukum Universitas Mataram;

Kurniawan dan Abdul Wahab. "Tinjauan Yuridis Terhadap Prosedur Penyelesaian Sengketa Konsumen Melalui BPSK di Indonesia". J urnal Hukum J atiswara, Vol. 23, No. 2, Juli 2008 Fakultas Hukum Universitas Mataram;

Nasution, Az. "Aspek Hukum Perlindungan Konsumen". J urnal Teropong, Edisi Mei 2003, Masyarakat Pemantau Peradilan Indonesia

Nugroho, Susanti Adi. 2008. Proses Penyelesaian Sengketa Konsumen Di Tinjau dari Hukum Acara serta Kendala Implementasinya, J akarta: Kencana;

Parman, L. "Perlindungan Konsumen Dengan Sarana Hukum Pidana". Majalah IImiah Ilmu Hukum J atiswara Vol. 20 No. 2 April 2005 FH Universitas Mataram,

Purwadi, Ari. "Telaah Singkat tentang Undang Undang Perlindungan Konsumen". J urnal
Hukum \& Keadilan, Vol. 3. No. 3. 2000. FH UII Yogyakarta;

Rajagukguk, Erman. "Budaya Hukum dan Penyelesaian Sengketa Perdata di Luar Pengadilan". J urnal Magister Hukum, Vol. 2 No. 4, Oktober 2000. PPs-Ull, Yogyakarya;

Ramli, Ahmad. "Perlindungan Hukum Terhadap Konsumen Dalam Transaksi E-Commerce". Jurnal Hukum Bisnis, Volume 18 Nomor 3 Tahun 2002;

Sentosa, Mas Achmad. 20 Juli 2005, Peranan BPSK Terlalu Berat, tersedia di website www. hukumonline.com, diakses tanggal 5 Oktober 2009.

Sukandi, Suherdi. 6 November 2008, UUPK, Strategis Bagi Pergerakan Perlindungan Konsumen, BPSK Kota Bandung, tersedia di website www.google.com, diakses tanggal. 19 Desember 2009.

Sulistiyono, Adi. "Budaya Musyawarah Untuk Penyelesaian Sengketa Win-Win Solution Dalam Perspektif Hukum". Jurnal Hukum Bisnis, Vol. 25 No. 1, tahun 2006;

Suparman, Eman. 2004. Pilihan Forum Arbitrase dalam Sengketa Komersial untuk Penegakan Keadilan. Jakarta: PT. Tatanusa;

Wulandari, Bernadette T. "Badan Penyelesaian Sengketa Konsumen (BPSK) Sebagai Alternatif Upaya Penegakan Hak Konsumen di Indonesia". J urnal Gloria Juris, Vol. 6, Nomor 2. Mei-Agustus 2006. FH Unika Atma J aya, J akarta. 